\title{
Membrane Permeability of Cane Juice on Ultrafiltration with Several Kinds of Membrane
}

\author{
Masakuni TAKo and Sanehisa NAKAMURA \\ Laboratory of Sugar Technological Chemistry, College of Agriculture, \\ University of the Ryukyus, Nishihara-cho, Okinawa 903-01, Japan
}

Received June 26, 1985

\begin{abstract}
The effects of membrane permeability with several types with molecular weight cut-off levels of from 5,000 to 30,000 , on the flux and quality of raw and limed cane juice on ultrafiltration were studied by long-term testing for $2 \sim 3 \mathrm{hr}$. The flux of raw juice showed a remarkably high value when ultrafiltration was performed with a YM-30 membrane, for which the sucrose rejection was $5 \sim 7 \%$. The flux through a YM-5 membrane was the greatest, and the value did not drop during ultrafiltration of juice limed to $\mathrm{pH} 7.0$ at $85^{\circ} \mathrm{C}$. The sucrose rejection for the permeate with the YM5 membrane was very low, i.e. $0 \sim 1.2 \%$, for juice limed to $\mathrm{pH} 7.0$ at $85^{\circ} \mathrm{C}$.

The YM-30 membrane was suitable for the ultrafiltration of raw juice, while for juice limed under the optimum conditions of $\mathrm{pH} 7.0$ at $85^{\circ} \mathrm{C}$, the YM-5 membrane was more suitable.
\end{abstract}

We reported that the flux of cane juice on ultrafiltration was improved by adding lime. The degree of liming giving the greatest flux, the highest permeate quality based on purity, and the optimum contents of $\mathrm{CaO}$ and $\mathrm{P}_{2} \mathrm{O}_{5}$ were obtained at $\mathrm{pH} 8.1,7.8$ and 7.0 at 10,30 and $85^{\circ} \mathrm{C}$, respectively. ${ }^{1)}$ Furthermore, we also reported previously the membrane permeabilities of raw and limed juice through two types of membranes (PM and YM) with molecular weight cut-off levels of from 1,000 to 30,000 , and concluded that the YM-5 membrane, which had a nominal molecular weight exclusion limit of 5,000, was more suitable for ultrafiltration. ${ }^{2)}$ However, we did not discuss in detail the applicability of the membrane process in the sugar industry because unsatisfactory permeabilities were obtained for raw and limed juice with the two types of membranes, probably due to the difference in membrane material.

We describe here the effect of membrane permeability, with several types of YMmembrane with molecular weight cut-off levels of from 5,000 to 30,000 , on the flux and quality of raw and limed juice on ultrafiltration, as studied by long-term testing for $2 \sim 3 \mathrm{hr}$, and discuss the applicability of the membrane process in the cane sugar industry.

\section{MATERIALS AND METHODS}

Cane juice. Sugar cane (variety N: Co 310 ) grown in the fields of the University of the Ryukyus was pressed twice with a test mill to obtain juice, which was then filtrated through cotton wool.

Liming the cane juice. The cane juice $(400 \mathrm{ml})$ was limed to $\mathrm{pH} 8.1$ at $10^{\circ}$ and to $\mathrm{pH} 7.0$ at $85^{\circ} \mathrm{C}$ by the addition of $\mathrm{Ca}(\mathrm{OH})_{2}(3.4 \mathrm{~g} /$ liter $)$ as previously reported. ${ }^{1,2)}$

Operation and conditions for ultrafiltration. The apparatus used for ultrafiltration was a UHP-76 (Toyo Kagaku Sangyo Co., Ltd.), which is a batch-type filtration unit equipped with a stirrer. Five membranes of 2 types were used in this study: YM-30, YM-10, YM-5, and PM30 and PM-10 (Amicon Co., Ltd.). These membranes had nominal molecular weight exclusion limits of 30,000 , $10,000,5,000,30,000$ and 10,000, respectively, and the flow times for the initial $10 \mathrm{ml}$ for water were 33.0, 95.0, 133.0, 2.5 and $5.5 \mathrm{sec}$, respectively. The YM and PM membranes are reportedly made of a cellulose derivative and polysulfone, respectively. The juice applied $(370 \mathrm{ml})$ was ultrafiltered until a permeation volume of $360 \mathrm{ml}$ was reached $\left(700 \mathrm{rpm}, 4.0 \mathrm{~kg} / \mathrm{cm}^{2}\right.$ and $67^{\circ} \mathrm{C}$ ).

Sucrose measurements The Brix degrees of the permeated juice were measured with a refractometer and a 
spindle without clarification. The sucrose content was also measured with a saccharimeter after clarification with dry basic lead acetate for raw and permeated juice.

\section{RESULTS}

The membrane permeability of raw cane juice was examined in a previous study ${ }^{2)}$ until a permeation volume of $100 \sim 200 \mathrm{ml}$ per $370 \mathrm{ml}$ of the feed juice on ultrafiltration was reached, using two types of membranes (PM-30 and PM 10; YM-5 and YM-2), which had nominal molecular weight exclusion limits of 30,000 , $10,000,5,000$ and 1,000, respectively. When ultrafiltration was carried out with the YM-5 membrane, the flux rate was found to be as great as that with the PM-30 and PM-10 membranes. Furthermore, it remained at the high value after a permeation volume of $70 \sim 100 \mathrm{ml}$ was reached in contrast to in the case of the PM-30 and PM-10 membranes, for which the flux gradually decreased with increasing permeate volume. In order to comparatively study the membrane permeability for cane juice in more detail, a long-term test was performed for $2 \sim 3 \mathrm{hr}$ until a permeation volume of $360 \mathrm{ml}$ per $370 \mathrm{ml}$ of the feed juice was reached, using a series of YM membranes with molecular weight cut-off levels of
$30,000 \sim 5,000$. The same ultrafiltration test was also performed with PM-30 and PM-10 membranes. The flux rate is shown in Fig. 1 as a function of the permeate volume of the raw juice for the YM-30, YM-10, YM-5, PM-30 and PM-10 membranes. In spite of the greater flow rates for water through the PM membranes, these membranes showed lower flux rates for raw juice as compared to the YMmembranes. Furthermore, the flux rate for raw

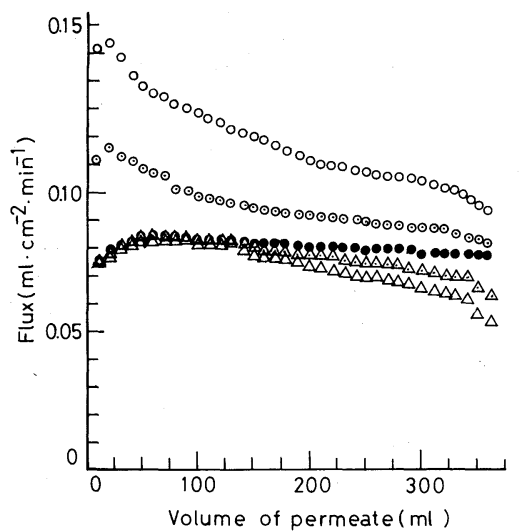

Fig. 1. Permeation Flux of Raw Juice as a Function of Permeation Volume at $67^{\circ} \mathrm{C}$.

The membrane used were Amicon YM-30, YM-10, YM-5, PM-30 and PM-10 membranes, respectively. Pressure, $4.0 \mathrm{~kg} \cdot \mathrm{cm}^{-2}$; stirring speed, $700 \mathrm{rpm} . \bigcirc, \mathrm{YM}-30 ; \odot, \mathrm{YM}-$ $10 ; \bigcirc$, YM-5; $\triangle$, PM-30; $\triangle$, PM-10.

Table I. Sucrose Contents of Raw Juice Permeated with YM-30, YM-10, YM-5, PM-30 and PM-10 Membranes at $67^{\circ} \mathrm{C}$

\begin{tabular}{lccc}
\hline & Sucrose $(\%, \mathrm{w} / \mathrm{v})^{*}$ & Bx (Spindle) & Bx (Ref) \\
\hline YM-30 & & & 20.1 \\
Sucrose & 17.9 & 22.7 & 4.98 \\
Sucrose rejection $(\%)^{a}$ & 6.71 & 7.49 & 19.2 \\
YM-10 & 18.1 & 21.0 & 4.23 \\
Sucrose & 5.57 & 5.28 & 16.2 \\
Sucrose rejection $(\%)^{a}$ & & 18.0 & 5.26 \\
YM-5 & 15.5 & 5.26 & 16.0 \\
Sucrose & 5.88 & 17.5 & 8.05 \\
Sucrose rejection $(\%)^{a}$ & 15.6 & 10.26 & 16.0 \\
PM-30 & 9.90 & 17.6 & 8.45 \\
Sucrose & 15.5 & 9.74 & \\
Sucrose rejection $(\%)^{a}$ & 9.88 & & \\
PM-10 & & & \\
Sucrose & & & \\
Sucrose rejection $(\%)^{a}$ & & & \\
\hline
\end{tabular}

* Measurement was performed after clarification with dry basic lead acetate.

a $\quad$ Sucrose rejection $=(1$-permeated juice $/$ feed juice $) \times 100$. 
juice decreased gradually with increasing permeation volume. The YM-30 membrane gave the highest flux rate, which decreased, however, gradually with increasing permeate volume. A decreasing flux rate was also observed with all the other membranes used, which may be due to the adsorption of some colloids such as proteins and polysaccharides on the membrane surface. Particularly, the flux with the PM-30 and PM-10 membranes was low in the initial stage, indicating the occurrence of considerable colloidal adsorption on the membrane material.

The qualities of the permeates are summarized in Table I. The permeates thus obtained were of $17 \sim 20^{\circ}$ Brix and $85 \sim 90 \%$ purity. Sucrose rejection was high, $8 \sim 10 \%$, with the PM membranes, while it was lower, $5 \sim 7 \%$, with the YM membranes. This may be due to the adsorption of some colloids mentioned above, and these results agree with the flux data shown in Fig. 1.

The limed juice adjusted to $\mathrm{pH} 8.1$ at $10^{\circ} \mathrm{C}$ was ultrafiltrated through the YM-30, YM-10, YM-5, PM-30 and PM-10 membranes, and the fluxes obtained are shown in Fig. 2. For all membranes tested, except the PM-30 one, practically the same flux values were observed, which decreased gradually with increasing permeate volume. The fluxes with the YM-30 and YM-10 membranes were lower than those for non-treated juice as shown in Fig. 1. The result obtained was contrary to our expectation. On the other hand, the initial flux with the PM-30 membrane was remarkably high and then the value decreased rapidly until a permeation volume of $150 \mathrm{ml}$ was reached and then gradually as in the cases of the other membranes.

Figure 3 shows the flux-permeate relationship of juice limed to $\mathrm{pH} 7.0$ at $85^{\circ} \mathrm{C}$. The fluxes through the PM-30 and PM-10 membranes showed greater initial values than those with the YM-30, YM-10 and YM-5 membranes, while they decreased as in the case of juice limed to $\mathrm{pH} 8.1$ at $10^{\circ} \mathrm{C}$ (Fig. 2). On the contrary, the YM-5 membrane gave a constant flux rate during the ultrafiltration, the greatest value being seen after a permeation volume of

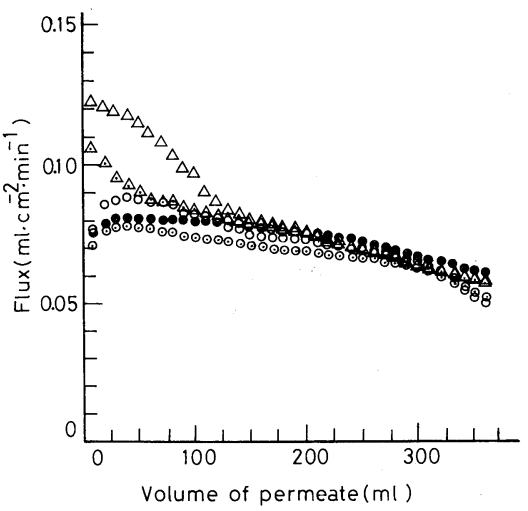

FIG. 2. Permeation Flux of Juice Limed to $\mathrm{pH} 8.1$ at $10^{\circ} \mathrm{C}$ as a Function of Permeation Volume at $67^{\circ} \mathrm{C}$.

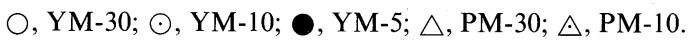

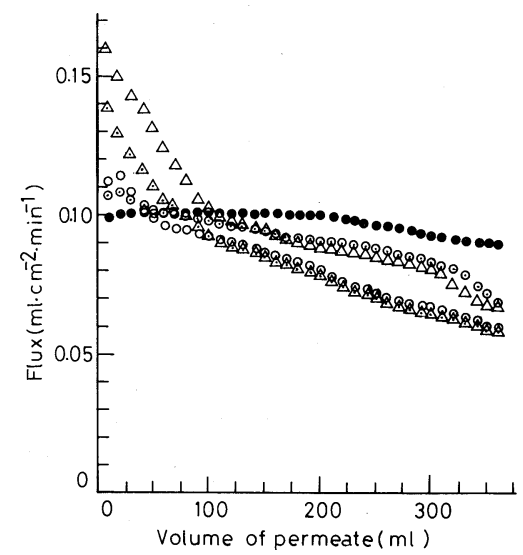

FIG. 3. Permeation Flux of Juice Limed to $\mathrm{pH} 7.0$ at $85^{\circ} \mathrm{C}$ as a Function of Permeation Volume at $67^{\circ} \mathrm{C}$.

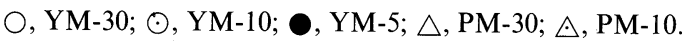

$90 \mathrm{ml}$ had been reached. The flux of the juice limed to $\mathrm{pH} 7.0$ at $85^{\circ} \mathrm{C}$ was greater for all of the membranes than that of the juice limed to $\mathrm{pH} 8.1$ at $10^{\circ} \mathrm{C}$ (Fig. 2), proving that hot liming to $\mathrm{pH} 7.0$ at $85^{\circ} \mathrm{C}$ is more effective for increasing the flux than cold liming at $\mathrm{pH} 8.1$ at $10^{\circ} \mathrm{C}$. This result agreed with the fact that smaller amounts of proteins and polysaccharides were observed in the permeates after hot liming as compared to those after cold liming, as reported previously. ${ }^{2)}$

The quality of juice limed to $\mathrm{pH} 8.1$ (7.0) at $10^{\circ}\left(85^{\circ}\right) \mathrm{C}$ and ultrafiltrated through various membranes is summarized in Table II. The sucrose rejection with PM membranes was 
Table II. Sucrose Contents of Limed Juice Permeated with YM-30, YM-10, YM-5, PM-30 and PM-10 Membranes at $67^{\circ} \mathrm{C}$

\begin{tabular}{|c|c|c|c|c|}
\hline & & Sucrose $(\%, w / v)$ & Bx (Spindle) & $B x(\operatorname{Ref})$ \\
\hline \multirow[t]{4}{*}{ YM-30 } & Limed to $\mathrm{pH} 7.0$ at $85^{\circ} \mathrm{C}$ & 15.3 & 16.2 & 15.3 \\
\hline & Sucrose rejection $(\%)^{a}$ & 3.23 & 4.44 & 3.77 \\
\hline & Limed to $\mathrm{pH} 8.1$ at $10^{\circ} \mathrm{C}$ & 15.2 & 16.0 & 15.0 \\
\hline & Sucrose rejection $(\%)^{a}$ & 4.00 & 6.67 & 5.66 \\
\hline \multirow{4}{*}{ YM-10 } & Limed to $\mathrm{pH} 7.0$ at $85^{\circ} \mathrm{C}$ & 15.2 & 16.3 & 15.1 \\
\hline & Sucrose rejection $(\%)^{a}$ & 3.14 & 4.49 & 2.56 \\
\hline & Limed to $\mathrm{pH} 8.1$ at $10^{\circ} \mathrm{C}$ & 15.2 & 16.0 & 15.2 \\
\hline & Sucrose rejection $(\%)^{a}$ & 3.89 & 6.12 & 5.03 \\
\hline \multirow[t]{4}{*}{ YM-5 } & Limed to $\mathrm{pH} 7.0$ at $85^{\circ} \mathrm{C}$ & 16.3 & 17.0 & 16.1 \\
\hline & Sucrose rejection $(\%)^{a}$ & 1.2 & 0.0 & 0.58 \\
\hline & Limed to $\mathrm{pH} 8.1$ at $10^{\circ} \mathrm{C}$ & 16.2 & 17.1 & 16.4 \\
\hline & Sucrose rejection $(\%)^{a}$ & 5.27 & 3.9 & 3.53 \\
\hline \multirow[t]{4}{*}{ PM-30 } & Limed to $\mathrm{pH} 7.0$ at $85^{\circ} \mathrm{C}$ & 15.5 & 16.9 & 16.2 \\
\hline & Sucrose rejection $(\%)^{a}$ & 2.62 & 3.23 & 1.82 \\
\hline & Limed to $\mathrm{pH} 8.1$ at $10^{\circ} \mathrm{C}$ & 15.3 & 17.0 & 16.1 \\
\hline & Sucrose rejection $(\%)^{a}$ & 9.0 & 10.1 & 8.5 \\
\hline \multirow[t]{4}{*}{ PM-10 } & Limed to $\mathrm{pH} 7.0$ at $85^{\circ} \mathrm{C}$ & 15.8 & 16.9 & 16.2 \\
\hline & Sucrose rejection $(\%)^{a}$ & 2.52 & 2.72 & 1.82 \\
\hline & Limed to $\mathrm{pH} 8.1$ at $10^{\circ} \mathrm{C}$ & 15.3 & 16.9 & 16.0 \\
\hline & Sucrose rejection $(\%)^{a}$ & 14.94 & 14.76 & 14.87 \\
\hline
\end{tabular}

a Sucrose rejection $=(1$-permeated juice $/$ feed juice $) \times 100$.

higher than that with YM membranes in both the hot and cold liming tests. In the case of the YM membranes, the sucrose rejection did not increase with decreasing molecular weight cutoff level of the membranes used, if liming was performed to $\mathrm{pH} 7.0$ at $85^{\circ} \mathrm{C}$. Moreover, the reverse correlation was observed; namely, the YM-30 membrane, which had a molecular weight cut-off level of 30,000 , showed the highest sucrose rejection of $3.2 \sim 4.4 \%$ for the juice limed to $\mathrm{pH} 7.0$ at $85^{\circ} \mathrm{C}$ as compared to $4.0 \sim 6.7 \%$ for the juice limed to $\mathrm{pH} 8.1$ at $10^{\circ} \mathrm{C}$. The sucrose rejection with the YM-10 membrane was $2.5 \sim 4.5 \%$ and $3.9 \sim 4.5 \%$ for the juice limed to $\mathrm{pH} 7.0$ at $85^{\circ} \mathrm{C}$, and $\mathrm{pH} 8.1$ at $10^{\circ} \mathrm{C}$, respectively. The lowest sucrose rejection was obtained with the YM-5 membrane, the values being $0.1 \sim 1.2 \%$ and $3.5 \sim 5.3 \%$, respectively. The sucrose rejection with the PM-30 and PM-10 membranes was low, $1.8 \sim 3.2 \%$ and $1.8 \sim 2.7 \%$, respectively, for the juice limed to $\mathrm{pH} 7.0$ at $85^{\circ} \mathrm{C}$, while these membranes showed very high values of

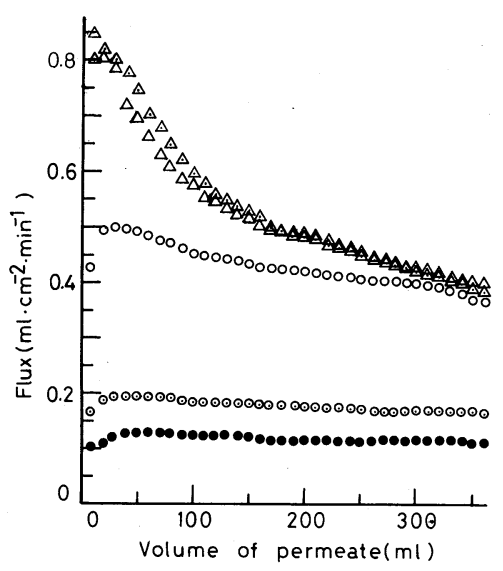

FIG. 4. Permeation Flux of a Sucrose Solution as a Function of Permeation Volume at $67^{\circ} \mathrm{C}$.

The sucrose solution used was $17.5 \%$ w/v. $\bigcirc$, YM-30; $\odot$, YM-10;, YM-5; $\triangle$, PM-30; $\triangle$, PM-10.

$8 \sim 10 \%$ and $15 \%$ for the juice limed to $\mathrm{pH} 8.1$ at $10^{\circ} \mathrm{C}$, respectively.

Experimental results were also obtained for a pure sucrose solution $(17.5 \%, \mathrm{w} / \mathrm{v})$, as shown in Fig. 4. In both experiments with PM-30 and 
PM-10 membranes, remarkable high values were observed during the initial period, which then decreased with increasing permeate volume, suggesting that sucrose adsorption occurred on the membrane used for the pure sucrose solution. The proportional correlation was found between the cut-off molecular weight and the flux for the YM membranes; namely, the flux rate decreased with decreasing molecular weight cut-off level. As for the YM-5 membrane, a small increase in the fulx was observed as compared to that of the cane juice limed to $\mathrm{pH} 7.0$ at $85^{\circ} \mathrm{C}$ (Fig. 3). The sucrose rejection for pure sucrose solutions was very low, $0 \sim 1.5 \%$, with both $\mathrm{YM}$ and PM membranes (not cited in the table).

\section{DISCUSSION}

A number of studies have been performed on the application of low-energy techniques in sugar processing, because cane manufacturing is one of the most energy-intensive processes in the food industry. ${ }^{4)}$ One such technique is the ultrafiltration of raw and limed juice. ${ }^{5 \sim 8)}$ As reported previously, addition of lime to cane juice proved effective for increasing the flux. ${ }^{1)}$ When ultrafiltration was carried out through a PM-10 membrane at. $80^{\circ} \mathrm{C}$ after liming at 10 , 30 and $85^{\circ} \mathrm{C}$, the greatest flux and highest permeate quality based on purity, and the optimum contents of $\mathrm{CaO}$ and $\mathrm{P}_{2} \mathrm{O}_{5}$ were obtained at $\mathrm{pH} 8.1,7.8$ and 7.0, respectively. Such optimum conditions were also found for YM-5 and YM-2 membranes. ${ }^{2)}$ In this study, batch-type filtration with stirring was performed for $2 \sim 3 \mathrm{hr}$ through YM membranes with molecular weight cut-off levels of from 30,000 to 5,000 at $67^{\circ} \mathrm{C}$ after liming to $\mathrm{pH} 8.1$ at $10^{\circ} \mathrm{C}$, and $\mathrm{pH} 7.0$ at $85^{\circ} \mathrm{C}$. Similar tests were also carried out with PM-30 and PM-10 membranes for comparison.

In spite of the greater flow rate for water through PM membranes as compared to YM membranes, the formers showed lower flux values than the latters for raw cane juice. Furthermore, the flux through a YM-30 membrane was great, $0.153 \mathrm{ml} \cdot \mathrm{cm}^{-2} \cdot \min ^{-1}$, in the initial stage, while it then decreased gradually with increasing permeate volume, being $0.105 \mathrm{ml} \cdot \mathrm{cm}^{-2} \cdot \mathrm{min}^{-1}$ at a permeation volume of $300 \mathrm{ml}$ per $370 \mathrm{ml}$ for the feed juice. A similar phenomenon was observed with the YM-10 membrane, which showed a comparatively large flux value as compared to the YM5, PM-30 and PM-10 membranes. The value obtained with the YM-30 membrane was as large that obtained on ultrafiltration at $80^{\circ} \mathrm{C}$ through the PM-10 membrane under the optimum liming conditions of $\mathrm{pH} 7.0$ at $85^{\circ} \mathrm{C}^{1}{ }^{1)}$ This suggests that the present purification method directly gives juice which can go to the evaporator without further purification for white sugar production, when the YM-30 membrane is used in the sugar industry.

However, the flux obtained with the YM-30 membrane was lower, even in the initial stage, than those with the YM-5, PM-30 and PM-10 membranes after liming to $\mathrm{pH} 7.0$ at $85^{\circ} \mathrm{C}$. For all these membranes, except the YM-5 one, the flux decreased with increasing permeate volume, and the values were smaller than those obtained with the YM-5 membrane after a permeate volume of $50 \sim 90 \mathrm{ml}$ had been reached. As previously reported, ${ }^{2)}$ the flux rate through the YM-5 membrane remained at a constant value of $0.100 \mathrm{ml} \cdot \mathrm{cm}^{-2} \cdot \mathrm{min}^{-1}$ during ultrafiltration until a permeation volume of $360 \mathrm{ml}$ per $370 \mathrm{ml}$ of feed juice was reached, suggesting that little adsorption of colloids such as proteins and polysaccharides occurred on the surface of the membrane.

In spite of the high flux values with the YM30 and YM-10 membranes observed for raw juice, the flux of juice was lower than that obtained with the YM-5 membrane after liming to $\mathrm{pH} 7.0$ at $85^{\circ} \mathrm{C}$. This may be due to a change in conformation of proteins and glycoproteins dissolved in the juice. Protein molecules may have a globular conformation in raw juice. However, liming seems to convert $40 \%{ }^{2)}$ of the polymers into random conformations. The low flux values for limed juice with the YM-30 and YM-10 membranes may be due to the adsorption of such polymers on the membranes, However, with 
the YM-5 membrane, adsorption did not occur. Presumably, the soluble polymers are too large to be adsorbed on the membrane surface. The low flux with the PM membranes (PM-30 and PM-10) for raw juice may be due to the remarkable adsorption of proteins that takes place, even of polymers globular in shape.

The sucrose rejection for the PM membranes was greater than that for the YM membranes for both raw juice and that limed to $\mathrm{pH} 8.1$ at $10^{\circ} \mathrm{C}$. This indicates that there is a remarkable difference in sucrose concentration between the residual and permeated juice when ultrafiltration is performed with PM membranes. This implies an osmotic pressure increase during the ultrafiltration due to the increase in sucrose concentration in the feed juice caused by the polymer adsorption on the PM membrane. ${ }^{9)}$ The effect of osmotic pressure on the flux of juice was negligible when ultrafiltration was performed with YM membranes, because the sucrose rejection was very low except in the case of raw juice. ${ }^{10)}$

On ultrafiltration of raw and limed juice with the YM and PM membranes, a dark brown deposit was formed on the membrane surface. By washing with $0.05 \mathrm{~N} \mathrm{NaOH}$ at $60^{\circ} \mathrm{C}$ for $20 \mathrm{~min}$, the deposit adsorbed on the YM membranes was removed and the membrane capacity was restored. On the contrary, the original capacity of the PM membranes was not recovered with the above washing process. Thus, PM membranes are difficult to use in the sugar industry. A big problem in ultrafiltration is the fouling of membranes. ${ }^{7}$ This could cause serious disruption of sugar production and limit the economic viability of the process. As mentioned under Results AND Discussion, this problem can be overcome by the use of
YM membranes, which are reportedly made of a cellulose derivative. Thus, we conclude that the YM-30 membrane is suitable for raw juice, while the YM-5 membtrane is more suitable for limed juice.

The next stage in this study is large scale operation with a YM membrane, using a batch-type filtration apparatus and other systems such as tubular, spiral wound and hollow-fibre ones.

Acknowledgments. We wish to thank Dr. Danji Nomura, Professor at Toa University, Dr. Yoshihiro Kohda, Professor at the University of the Ryukyus, and Dr. Kohichi Hashimoto of Toriko Co., Ltd. for their valuable advice, and Mr. Mitsuru Takara for his technical assistance.

This work was supported in part by a Grant-in-Aid for Scientific Research (No. 59390021) from the Ministry of Education, Science and Culture of Japan.

\section{REFERENCES}

1) M. Tako, Y. Nakayama, S. Nakamura, S. Kishihara and M. Komoto, Nippon Nôgeikagaku Kaishi, 58, 685 (1984).

2) M. Tako, M. Takara and S. Nakamura, Nippon Nôgeikagaku Kaishi, 59, 779 (1985).

3) S. Kishihara, S. Fujii and M. Komoto, Int. Sugar J., 83, 35 (1981).

4) S. Kishihara, S. Fujii and M. Komoto, Membrane, 5, 86 (1980).

5) R. F. Madsen, Int. Sugar J., 75, 163 (1973).

6) G. W. Vane, La Sucrerie Belge, 96, 277 (1977).

7) T. R. Hanssens, J. G. M. Van Nispen, K. Koerts and L. H. de Nie, Int. Sugar J., 86, 227 (1984).

8) T. R. Hanssens, J. G. M. Van Nispen, K. Koerts and L. H. de Nie, Int. Sugar J., 86, 240 (1984).

9) C. D. Hodgman, "Handbook of Chemistry and Physics," Chemical Rubber Publishing Co., Ltd., Cleveland, 1939, p. 1334.

10) K. Hashimoto, "Shokuhin Kogyo to Maku Riyo," ed. by D. Nomura and H. Ohya, Saiwai Shobo, 1983, p. 277. 